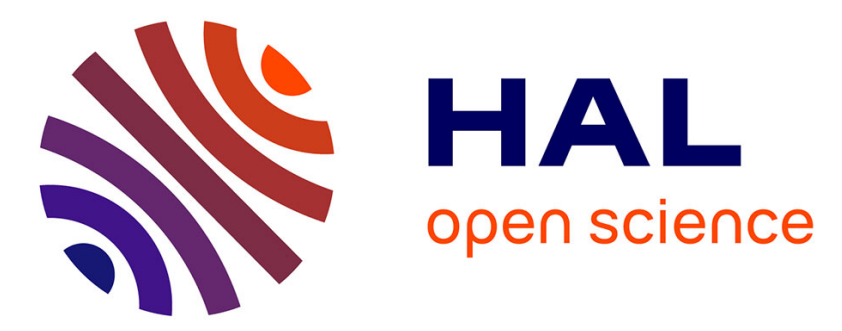

\title{
Expression, localization, and inducibility by bile acids of hepatobiliary transporters in the new polarized rat hepatic cell lines, Can 3-1 and Can 10.
}

Doris Cassio, Rocio I. R. Macias, Brigitte Grosse, Jose J. G. Marin, Maria J. Monte

\section{To cite this version:}

Doris Cassio, Rocio I. R. Macias, Brigitte Grosse, Jose J. G. Marin, Maria J. Monte. Expression, localization, and inducibility by bile acids of hepatobiliary transporters in the new polarized rat hepatic cell lines, Can 3-1 and Can 10.. Cell and Tissue Research, 2007, 330 (3), pp.447-60. 10.1007/s00441007-0494-3 . inserm-00276792

\section{HAL Id: inserm-00276792 https://www.hal.inserm.fr/inserm-00276792}

Submitted on 2 May 2008

HAL is a multi-disciplinary open access archive for the deposit and dissemination of scientific research documents, whether they are published or not. The documents may come from teaching and research institutions in France or abroad, or from public or private research centers.
L'archive ouverte pluridisciplinaire HAL, est destinée au dépôt et à la diffusion de documents scientifiques de niveau recherche, publiés ou non, émanant des établissements d'enseignement et de recherche français ou étrangers, des laboratoires publics ou privés. 


\section{HAL author manuscript}

Expression, localization, and inducibility by bile acids of hepatobiliary transporters in new polarized rat hepatic cell lines, Can 3-1 and Can 10.

Doris Cassio $^{1,2}$, Rocio I.R. Macias ${ }^{3}$, Brigitte Grosse ${ }^{1,2}$, Jose J.G. Marin ${ }^{3}$, Maria J. Monte ${ }^{3}$

${ }^{1}$ INSERM, U757, University of Orsay, 91400, Orsay, France,

${ }^{2}$ University of Orsay, 91400, Orsay, France,

${ }^{3}$ Laboratory of Experimental Hepatology and Drug Targeting (HEVEFARM), CIBERehd, University of Salamanca, 37007 Salamanca, Spain.

\section{Contact information: Doris Cassio}

Unité INSERM 757, Bâtiment 443,

Université Paris-Sud, 91405 Orsay Cedex, France

Phone: 33169156858

Fax: 33169155893

e-mail: doris.cassio@ibaic.u-psud.fr 


\section{Abstract}

Sinusoidal and apical transporters are responsible for the uptake and biliary elimination of many compounds by hepatocytes. Few in vitro models are available for analyzing such functions. The expression and bile acid-inducibility of thirteen transporters and two nuclear receptors were investigated in new rat polarized lines, Can 3-1 and Can 10, and their unpolarized parent Fao. Relative abundance of mRNA, protein level and localization were examined by real-time quantitative PCR, Western blotting, immunofluorescence and confocal microscopy. Compared to rat liver, mRNA levels of Fao cells were: negligible for Bsep/Abcb11, lower for the uptake transporters (Ntcp, Oatps), similar for SHP, FXR and Bcrp/Abcg2, higher (4-160 fold) for the efflux pumps Mdr1b/Abcb1b, Mdr2/Abcb4, Mrp1/Abcc1, Mrp2/Abcc2, Mrp3/Abcc3, Abcg5, Abcg8. This profile was mostly maintained, and improved for Bsep, in Can 10. Some transporters were less expressed in Can 3-1. Moreover, in both lines sinusoidal (Ntcp, Mrp3) and canalicular transporters (Mdr-Pglycoproteins detected with C219 antibody, Mrp2) were localized at their correct poles. Bile acid-effects on polarity and mRNA levels of transporters were analyzed after a 6 daystreatment with $50 \mu \mathrm{M}$ of taurocholic, chenodeoxycholic (CDCA) or ursodeoxycholic acid (UDCA): no polarization of Fao cells was induced; Can 10 and Can 3-1 polarity was maintained; CDCA and UDCA induced marked enhancement of the volume of Can 10 bile canaliculi. CDCA upregulated Bsep, Mdr2, SHP, Mdr1b and Oatp2/1a4 in Can 10 (2-7 fold), and Fao cells. In conclusion, Can 10 constitutes an attractive polarized model for studying vectorial hepatobiliary transport of endogenous and xenobiotic cholephilic compounds.

Key words: hepatobiliary transporters, nuclear receptors, bile acids, hepatocyte polarity, cell models

List of abbreviations: Abc/ABC, ATP-binding cassette; BC, bile canaliculi; Bcrp, breast cancer resistance protein; Bsep/BSEP, bile salt export pump; CDCA, chenodeoxycholic acid; DPPIV, dipeptidylpeptidase IV; FITC, fluorescein isothiocyanate; FXR, farnesoid X activated receptor; Mdr/MDR, multidrug resistance protein; Mrp/MRP, multidrug resistance-associated protein; Ntcp, $\mathrm{Na}^{+}$-taurocholate co-transporting polypeptide; PBS: phosphate-buffered saline; Oatp/OATP, organic anion transporting polypeptide; PM: plasma membrane; SHP, small heterodimer partner; TCA, taurocholic acid; UDCA, ursodeoxycholic acid; 


\section{Introduction}

Bile secretion and biliary elimination of drugs are major functions of hepatocytes. These functions are fulfilled owing to the activity of a large panel of transporters located at the sinusoidal or at the apical pole of the plasma membrane (PM) of hepatocytes (Ito et al. 2005; Trauner and Boyer 2003; St Pierre et al. 2001). Few in vitro models are available for analyzing such functions. Ideally in a pertinent model, transporters should be produced at levels similar to those of liver, localized at the appropriate PM pole, regulated as in vivo, and functional.

Few models have been characterized for the gene expression and regulation of a large set of transporters, and models that stably express typical hepatocyte polarity are rare. The more complete studies were done with human hepatoma lines, such as Hep G2 (Knowles et al. 1980) and HepaRG (Parent et al. 2004). Although Hep G2 cells express genes of some transporters (as MRP2/ABCC2, MRP3/ABCC3, BSEP/ABCB11, ..) (Cantz et al. 2000, Kubitz et al 2004), the expression of others (as OATP2, now termed as OATP1B1), was absent or very week (Nakai et al. 2001; Le Vee et al. 2006). Moreover Hep G2 is not fully polarized since only 10 to $30 \%$ of cells are engaged in bile canaliculi (BC) formation (Kubitz et al 2004, Van Ijzendoorn et al. 2004). HepaRG cells displayed a better gene expression pattern of transporters (Le Vee et al. 2006), but their polarity state remains to be precisely characterized, all the more because they are bipotent cells that can differentiate either as hepatocytes or cholangiocytes (Parent et al. 2004).

Starting from the non polarized but well differentiated rat hepatoma line Fao we first isolated polarized rat-human hybrid cells (Cassio et al. 1991), leading to isolation of the WIFB and WIF-B9 lines (Ihrke et al. 1993; Shanks et al. 1994; Decaens et al. 1996). These cells are able to vectorially transport in BC a fluorescent bile acid analogue (Bravo et al., 1998). They produce at a robust level some rat hepatobiliary transporters and at a low level a few human transporters (Nies et al. 1998, Briz et al. 2003; Briz et al. 2007). However, their 
complex chromosomal content is very far from that of Fao and they form only simple BC, namely BC between two or three cells (Ihrke et al. 1993). Recently, we isolated by growing transiently Fao cells in spheroids, two new polarized lines, Can 3-1 and Can 10 (Peng et al. 2006). These cells display a chromosomal content similar to that of their rat parental cells. They are fully polarized and form BC, in which bile acid derivatives (such as cholylglycylamido fluorescein), organic cations (such as rhodamine 123), and organic anions (such as fluorescein) are vectorially transported (Peng et al. 2006). Interestingly the BC structures of Can 10 cells are highly developed, as those formed in vivo.

The present study was designed to investigate in these new polarized lines and their unpolarized parent the expression and inducibility by bile acids of a large panel of genes encoding proteins implicated in bile acid and drug transport, namely thirteen transporters and two nuclear receptors. The localization of some transporters was examined in parallel. Our results designated Can 10 cells as a good model for analyzing several aspects of the physiology and pharmacology of the hepatobiliary transport of endogenous (e.g. bile acids) and xenobiotic (e.g. drugs) cholephilic compounds. 


\section{Materials and methods}

\section{Materials}

Fetal bovine serum was from Gibco BRL (Invitrogen, Cergy Pontoise, France). Culture medium, medium supplements, dimethyl sulfoxide (DMSO), bile acids and $\tilde{\alpha}$ tubulin antibody, were from Sigma Chemical Company (St. Louis, MO, USA). Rabbit polyclonal antibodies against Mrp2/Abcc2 (Buchler et al. 1996) and guinea pig polyclonal antibodies against Mrp3/Abcc3 (Donner and Keppler 2001) were given by D. Keppler. Rabbit polyclonal antibodies directed against $\mathrm{Na}^{+}$-taurocholate cotransporting polypeptide, $\mathrm{Ntcp}$, was a gift from B. Stieger (Stieger et al. 1994). The mouse monoclonal anti-P-glycoprotein C219 was purchased from Dako, (Carpinteria, CA, USA); it recognizes Mdr1a, Mdr1b and Mdr2. Rabbit polyclonal antibodies against dipeptidylpeptidase IV (DPPIV) and rat monoclonal antibodies against the tight junction associated protein, ZO-1 were provided by A. Hubbard (Shanks et al. 1994) and by B.R. Stevenson (Stevenson et al. 1986), respectively. Fluorescent Alexa dye-conjugated and horseradish peroxidase-linked secondary antibodies were from Molecular Probes (Eugene, OR, USA) and Amersham Biosciences Europe (Orsay, France), respectively. FITC-conjugated goat antibodies directed against guinea pig IgG were from Sigma.

\section{Cell lines}

The unpolarized Fao line (Deschatrette and Weiss 1974) is a subclone of the rat hepatoma H4IIEC3 line. Can 3-1 and Can 10 are stable highly polarized cell lines obtained by transient spheroid culture of Fao cells (Peng et al., 2006). Their caryotype, growth rate and production of epithelial markers (such as E cadherin) and tight junctional proteins (such as occludin) have been determined (Peng et al., 2006). These lines are available (INSERM, U757, University of Orsay, 91400, Orsay, France) for further studies on hepatocyte differentiation. 


\section{Cell Culture}

Cell culture was performed in Coon's modified F-12 medium exactly as described (Cassio et al. 1991). Fao and Can 10 cells were plated at $3.5 \times 10^{3} / \mathrm{cm}^{2}$. Can $3-1$ cells were plated at $10^{5} / \mathrm{cm}^{2}$; this high density is necessary for Can 3-1 polarization (Peng et al. 2006). Cells were cultured in $10 \mathrm{~cm}$ Petri dishes or glass coverslips for seven days. Cells grown in dishes were used for RNA extraction or protein lysate preparation. Cells on coverslips were used for immunolocalization and for FITC-dextrans paracellular diffusion studies.

\section{Treatment with bile acids}

Stock solutions $(50 \mathrm{mM})$ of bile acids, taurocholic (TCA), chenodeoxycholic (CDCA) and ursodeoxycholic acid (UDCA) were prepared in DMSO. Cells were cultured for 7 days. They were plated in normal medium and after one day they were cultured without (control) and with TCA, CDCA, UDCA $(50 \mu \mathrm{M})$ or DMSO, the final concentration of DMSO being $0.1 \%$. Those media were renewed twice (at day 3 and 6).

\section{Determination of gene expression by real-time RT-PCR}

Total RNA was isolated from cells using RNeasy spin columns from Qiagen (Izasa, Barcelona, Spain), treated with DNAse I (Roche, Barcelona, Spain), and measured with the RiboGreen RNA-Quantitation kit (Molecular Probes, Leiden, The Netherlands). RT was carried out using random nonamers and the Enhanced Avian RT-PCR kit (Sigma-Genosys, Cambridge, UK). Real-time quantitative PCR was performed using Amplitaq Gold polymerase (Perkin-Elmer Applied Biosystems, Madrid, Spain) in an ABI Prism 5700 Sequence Detection System (Perkin-Elmer Applied Biosystems) with the following thermal conditions: a single cycle of $95^{\circ} \mathrm{C}$ for 10 min followed by 45 cycles of $95^{\circ} \mathrm{C}$ for $15 \mathrm{~s}$ and $60^{\circ} \mathrm{C}$ 
for 60 s. Primer oligonucleotides obtained from Sigma-Genosys (Table 1) were designed with the assistance of Primer Express software (Perkin-Elmer Applied Biosystems) for cDNA fragments in described sequences, and their specificity was checked using BLAST. Since amplification products were detected using SYBR Green I, it was ascertained previously that no non-specific products were formed during PCR in any case (data not shown). Total liver RNA from a healthy male adult rat was used in all determinations as an external calibrator. The results obtained from each sample were normalized using both polyubiquitin-C and $18 \mathrm{~S}$ rRNA to correct the differences of RNA extraction in each sample. The latter was measured using the TaqMan ${ }^{\circledR}$ Ribosomal RNA Control Reagents kit (Perkin-Elmer Applied Biosystems).

\section{Immunolocalization of proteins}

Cells on glass coverslips were rinsed three times in PBS and then fixed. They were fixed in $3 \%$ formaldehyde $\left(4^{\circ} \mathrm{C}, 1 \mathrm{~min}\right)$ and permeabilized with methanol $\left(4^{\circ} \mathrm{C}, 15 \mathrm{~min}\right)$ for $\mathrm{Mrp} 2$ and DPPIV, or with acetone $\left(4^{\circ} \mathrm{C}, 2 \mathrm{~min}\right)$ for $\mathrm{Mdr}$ or $5 \mathrm{~min}$ at $-20^{\circ} \mathrm{C}$ in methanol followed by 1 min at $-20^{\circ} \mathrm{C}$ in acetone for Mrp3. For Ntcp localization cells were fixed in $4 \%$ formaldehyde $\left(4^{\circ} \mathrm{C}, 30 \mathrm{~min}\right)$, permeabilized with Triton $0,1 \%$ in PBS (room temperature, $3 \mathrm{~min}$ ) and then incubated with $10 \%$ serum in PBS (room temperature, 30 min). ZO-1 was localized using any of these fixations. After fixation, indirect immunofluorescence was performed (Bender et al. 1998) and cells were analyzed with a Zeiss Axioskop fluorescence microscope. Confocal analysis was performed with a Zeiss LSM 510 confocal microscope, with a x63 objective. Series of xy sections were taken in $0.3 \mu \mathrm{m}$ steps.

\section{Western blotting}

Cells cultured for 7 days were lysed as described (Bender et al. 1998). Proteins (25 $\mu \mathrm{g}$ ) from lysate aliquots were separated by 7.5\% SDS-PAGE (Laemmli 1970), then transferred to a nitrocellulose membrane (Hybond ECL, Amersham). Immunoblotting was performed using 
anti-P-glycoprotein $\mathrm{C} 219$ with anti $\alpha$-tubulin antibodies, and the appropriate peroxidaseconjugated secondary antibodies. Peroxidase activity was detected by enhanced chemiluminescence (kit from Amersham Biosciences Europe), and NIH Image 1.62 software was used for densitometric analysis.

\section{Tight junction paracellular permeability}

Paracellular permeability of tight junctions was evaluated by measuring the paracellular diffusion into the BC of FITC-dextrans (molecular weight 4,400). Cells grown on glass coverslips were washed once with serum-free medium, incubated exactly as previously described (Ihrke et al. 1993) with $3 \mathrm{mg} / \mathrm{ml} \mathrm{FITC-dextrans} \mathrm{for} 30 \mathrm{~min}$ at $2^{\circ} \mathrm{C}$ and washed two times with cold serum-free medium before observation. Each coverslip was examined within 5-10 min after mounting on a glass microscope slide. Fluorescent BC were counted and expressed as a percent of the total number of $\mathrm{BC}$ observed in phase contrast. For each culture, 2-3 coverslips were examined (4 fields per coverslip and at least $200 \mathrm{BC}$ observed).

\section{Statistical analysis}

Effects of bile acid treatment were analyzed using a Student's t-test. The criterion of significance was $\mathrm{p}<0.05$. 


\section{Results}

\section{Expression and localization of hepatobiliary transporters}

The steady state of relative abundance of mRNA of thirteen transporters and two nuclear receptors involved in hepatobiliary function was measured by real-time quantitative PCR in the unpolarized parental cell line Fao and in the polarized Can 3-1 and Can 10. Fao cells displayed a gene expression pattern near to that of liver (Fig. 1). Ten over the fifteen genes examined were expressed at $60 \%$ or more of the liver level. The expression of Ntcp was low $(3 \%)$ as well as that of the three isoforms of organic anion transporters involved in the uptake of bile acids by the rat liver, i.e., Oatp1/1a1 (0.7 \%), Oatp2/1a4 (23\%), Oatp4/1b2 (16\%). In contrast, high gene expression of most $\mathrm{ABC}$ transporters was found. Among the nine $\mathrm{ABC}$ genes examined, seven (Mdr1b, Mdr2, Mrp1, Mrp2, Mrp3, Abcg5 and Abcg8) were expressed at a higher level than in liver. This was particularly striking for Abcg5 and Abcg8, their mRNA being 80 and 160 times more abundant than in liver, respectively. The level of Bcrp was similar to that in normal rat liver, whereas that of Bsep was negligible $(0.04 \%)$. The gene expression of the nuclear receptor FXR and the transcription factor SHP was of the same order in Fao cells and liver.

When we examined the polarized lines, Can 3-1 and Can 10 (Fig. 2), we found that the gene expression pattern of Fao was almost maintained in these subclones, although some differences were observed. Can 3-1 cells displayed a significative lower level for Oatp4/1b2, Mdr2, Mrp2, Abcg5, Abcg8. Moreover in these cells Bsep mRNA could not be detected. Can 10 cells produced lower amounts of Oatp2/1a4 and Oatp4/1b2 mRNA whereas that of Mrp3, Bcrp and Bsep was increased. However Bsep mRNA level remained still very low (0.53\% of liver level). In both sublines mRNA level of FXR and SHP was reduced but attained at least $30 \%$ of the liver level. 
The next step of this study was to ascertain that hepatobiliary transporters were localized at their appropriate poles in polarized Can lines. Mdr proteins (detected with the C219 antibody, that recognizes Mdr1a, Mdr1b, Mdr2) and Mrp2 were chosen as typical apical transporters; Mrp3 and Ntcp as basolateral ones. In non-polarized Fao cells, apical transporters were exclusively localized in an intracellular compartment (Fig. 3b,k), basolateral transporters were mostly present on the whole plasma membrane (Fig. 4b,k) and ZO-1 was discontinuously distributed on this membrane (Figs. 3c,1, 4c,1). In Can 3-1 and Can10 cells these proteins displayed a polarized localization (Figs. 3, 4). Apical transporters were confined in the BC delineated by the tight junction-associated protein ZO-1 (Fig. 3e,h,q). Basolateral transporters were excluded from $\mathrm{BC}$ and present on the rest of the PM and in the cytoplasm (Fig. 4e,h,n,q).

Thus, these two polarized sublines, in particular Can 10 cells expressed at a high level several hepatobiliary transporters, which are localized in similar PM domains to those of normal polarized hepatocytes.

\section{Effects of bile acids on tranporters expression, targeting, and polarity}

To investigate the effects of bile acids, cells were cultured for 6 days with taurocholic acid (TCA), chenodeoxycholic acid (CDCA) or ursodeoxycholic acid (UDCA). TCA was tested because it is the most abundant natural bile acid in rat bile (Monte et al. 1997), whereas CDCA, which is also abundant in this species, is a very strong natural ligand for the nuclear receptor FXR (Lew et al. 2004, Makishima et al. 1999). UDCA was included as comparison because it is a poor ligand for FXR (Lew et al. 2004, Makishima et al. 1999). However, this bile acid has very interesting properties regarding its ability to stimulate bile formation (Scharschmidt \& Lake, 1989). In each case $50 \mu \mathrm{M}$ was used because it is high enough to be considered as similar to serum total bile acid concentrations reaching the liver parenchyma in situations of mild cholestasis or transiently in postprandial periods. Moreover this 
concentration is low enough not to induce any toxic effect and it is far below the critical micellar concentration for most bile acid species. Indeed we have verified that it was not toxic for the three cell lines examined here.

No significant change in gene expression was observed in TCA- and UDCA-treated cells, whatever the line examined, except for Bsep in UDCA-treated Fao cells (Fig. 5g). In contrast the gene expression of some hepatobiliary transporters, namely Mdr2, Bsep, and to a lesser extent Mdr1b and Oatp2/1a4, together with that of SHP, was upregulated by CDCA in Fao and Can 10 cells (Fig. 5f,g,e,c,o). Bsep was the most markedly induced (280 fold in Fao and 7 fold in Can 10), but it was also by far the less expressed in non-treated cells. Its level reached $12 \%$ and $4 \%$ of liver level in Fao and Can 10 treated by CDCA, respectively. For the other CDCA-induced genes, a 2-4 fold increase was observed in CDCA-treated cells. In Can 10 cells cultured for only 3 days with CDCA, upregulation of Bsep, Mdr2 and SHP was already induced, but at a slightly lower level than after a 6 days-treatment (results not shown). No significant changes in gene expression were induced by treatment of Can 3-1 with CDCA.

The effect of CDCA on Mdr was examined at the protein level: Western blotting was performed and the protein was quantified (Fig. 6a,b). We effectively found a 4 fold increase in Fao and Can 10 cells cultured with CDCA, and no change in Can 3-1 cells.

Finally, the effects of bile acids on the polarized state of the three cell lines and on the targeting of transporters were investigated. No polarization of Fao cells was induced whatever the bile acid used (results not shown). In the case of Can 10 cells that form long tubular BC, enhancements of the volume of BC were induced by UDCA, CDCA, but not frequently by TCA (Fig. 7). However, polarity was well maintained in cells treated with bile acids, as illustrated by the localization of the apical marker DPPIV (Fig. 7b,d,f,h) and the confocal analysis of the localization of Mrp2 with ZO-1 (Fig. 7i-x) and of Mdr with ZO-1 (Fig. 8e-h). Can 3-1 polarity was also maintained after treatment with bile acids. Besides Mdr proteins were more concentrated in the $\mathrm{BC}$, and consequently better targeted, in CDCA-treated Can 3- 
1 cells (Fig. 8c,d). In the case of Can 10, these apical proteins were already correctly targeted to $\mathrm{BC}$ in non-treated cells (Fig. 8e,f).

The effect of bile acids on the paracellular permeability of tight junctions was evaluated using FITC-labeled dextrans. As shown in Fig. 9 paracellular permeability of both lines was enhanced in cells treated with bile acids. 


\section{Discussion}

The present study was designed to investigate in new polarized rat cell lines the gene expression, localization, and inducibility by bile acids of a large panel of proteins implicated in hepatobiliary transport. This analysis was undertaken for two reasons. Firstly, whereas most in vivo experiments on bile transport and biliary elimination of drugs are performed on rats, in vitro experiments are rarely performed with rat cell lines. Secondly, human hepatic cell lines, such as Huh7, Hep G2, Hep3B, PLC/PRF/5 are the most popular systems for in vitro studies, but most of them are poor models for transport studies, and are not or badly polarized.

\section{Comparison of the expression and localization of transporters in hepatic cell lines}

In the non-polarized parental Fao cells the majority of the thirteen transporters examined and the two nuclear receptors FXR and SHP are expressed at a level, similar and often higher than in liver. Strikingly, efflux transporters, whether they are apical or sinusoidal, are well expressed, except Bsep, whereas influx transporters expression is rather low. This expression profil is well maintained and even improved for some transporters, in Can 10 cells. In contrast several transporters, in particular Mrp2, are badly expressed in Can 3-1.

We recently analyzed the expression of seven transporters in the polarized rat-human hybrid WIF-B9 clone (Briz et al. 2007). Some transporters (Mdr1b, Mrp1, Mrp2) are expressed at similar levels in WIF-B9 and Can 10, but others (Bcrp, Mdr2, and to a lesser extent Bsep and Mrp3) are expressed at much lower levels in WIF-B9. So among the polarized clones established from Fao, Can 10 has the better gene expression pattern of transporters.

Two human cell lines Hep G2 and HepaRG were previously characterized for the gene expression of a dozen of transporters (Le Vee et al. 2006). As observed here for rat cell lines, these human lines are characterized by a very low expression of uptake transporters, and a 
better expression of efflux pumps. In this study mRNA levels were compared to levels of primary hepatocytes (and not to liver levels as in our study). Assuming that expression levels are not very different in liver and primary hepatocytes, the comparison between Can 10 and human lines levels shows that genes of transporters are better expressed in Can 10 than in Hep G2 and even HepaRG, except for Bsep that is well expressed in HepaRG cells.

Compared to Fao and human cell lines both Can sub-lines present the advantage to correctly localized transporters: apical transporters are present at the $\mathrm{BC}$ and basolateral transporters are absent from $\mathrm{BC}$ and present on the rest of the PM. These localizations were observed for all cells, attesting to the homogeneity and stability of the polarized phenotype of both Can clones. In the case of Mdr proteins detected with the C219 antibody, we observed a higher enrichment in $\mathrm{BC}$ with a weaker cytoplasmic staining in Can 10, suggesting a better targeting of these apical transporters in Can 10 than in Can 3-1 cells.

\section{Comparison of the effects induced by bile acids in hepatic cell lines}

The consequences of treatment of Fao, Can 3-1 and Can 10 cells by various bile acids were evaluated. CDCA is by far the most efficient of the three bile acids tested. As the other bile acids, CDCA induces increase of tight junction paracellular permeability of Can 3-1 and Can 10 cells. It also promotes, as UDCA, a marked enhancement in the volume of Can 10 BC. Such changes could result from the accumulation of bile acids in BC during the 6 days treatment. In contrast to TCA and UDCA, CDCA induces also in Fao and Can 10 cells upregulation of a same subset of transporters. CDCA is known to be the most efficient FXR activator (Lew et al. 2004) and the genes overexpressed in CDCA-treated Fao and Can 10 cells have been shown to be activated by bile acid-FXR-dependent mechanisms (Lee et al. 2006; Eloranta and Kullak-Ubrick, 2005). FXR response elements have been identified on the promoters of the most induced genes, Bsep, Mdr2 and SHP (Ananthanarayan et al. 2001; Huang et al. 2003; Goodwin et al. 2000; Lu et al. 2000). Consequently we attribute the 
overexpression of transporters occuring in CDCA-treated cells to FXR-mediated transcriptional activation.

Our data demonstrate that induction of gene expression and targeting of transporters are dissociable. Indeed in CDCA-treated Fao cells, some transporters are overexpressed but their localization is not improved and the cells remain unpolarized. Conversely a better targeting of Mdr proteins occurs in CDCA-treated Can 3-1 cells without any change in the mRNA level of these transporters. This improvement in targeting could result from some changes in cytoskeletal structures or components known to be involved in the targeting of apical transporters to the $\mathrm{BC}$, as for example myosin II light regulatory chain (Chan et al. 2005).

It has been previously shown that CDCA can reversibly induce polarization of Fao cells and Fao-derived revertant C2rev7 cells ( $\mathrm{Ng}$ et al. 2000). In our study, no sign of polarization was found in CDCA-treated Fao cells. This discrepancy might have been due to the fact that we used a lower and non-toxic CDCA concentration and a shorter period of treatment. Indeed, when we applied the drastic conditions described by $\mathrm{Ng}$ et al. (2000), no polarized cells were obtained. In the same way, when plated at low density, Can 3-1 cells did not polarize even in presence of CDCA.

Information about the effects of bile acids in other hepatic cell lines is scarce. The level of Ntcp is hardly increased (25\%) and its targeting to the BC slightly induced in TCtreated WIF-B9 cells (Konieczko et al. 1998; Sai et al. 1999). BSEP expression is downregulated by lithocholate and up-regulated by CDCA in Hep G2 cells (Yu et al. 2002; Lew et al. 2004). It is also highly induced by CDCA in HepaRG cells (Le Vee et al. 2006), but the effect of CDCA on other transporters was not examined. In none of the previous related studies, the effects of several bile acids on the gene expression of a large panel of transporters were analyzed. 


\section{Usefulness of Can 10 cells}

The aim of this study was to evaluate if the new rat polarized lines, Can 3-1 and Can 10, could be pertinent rat hepatic models for further in vitro studies on vectorial transport processes involved in the biliary secretion of bile acids and other cholephilic compounds. The most interesting line is undoubtely Can 10. Compared to their parental Fao cells, Can 10 cells have retained the same gene expression profile of transporters, many of these transporters being expressed at a level, similar and even higher than in the liver. Moreover the localization of these transporters was improved in Can 10 cells. Finally in Can 10 and Fao the expression of the same subset of transporters was induced by CDCA. This implies that Can 10 cells, while acquiring a polarized phenotype, have retained regulatory pathways controlling transporter levels. Another advantage of Can 10 is the formation of highly organized BC in which bile acids, organic anions and cations are vectorially transported (Peng et al. 2006).

In summary Can 10 is an interesting rat cell line for studying synthesis, regulation, and targeting of many hepatobiliary transporters. For example, since it expresses high levels of Abcg5 and Abcg8, it could be very useful to study how these transporters interact, traffic and promote biliary sterol excretion. Moreover, because of its functional polarity and its capacity of transport, Can 10 represents an attractive model for in vitro pharmacological and toxicological studies. 


\section{Acknowledgments}

We greatly thank A. Hubbard, D. Keppler, B.R. Stevenson, and B. Stieger for kindly providing antibodies. We also thank V. Nicolas (IFR141-ITFM, Chatenay Malabry, France) and Mickael Bourge (INSERM U757, Orsay, France) for help with confocal analysis and figure artwork, respectively. This work was supported by a grant from Egide (PAI Picasso) and the Acción Integrada Hispano-Francesa (HF2003-0089). The group is member of the Network for Cooperative Research on Membrane Transport Proteins (REIT), co-funded by the Ministerio de Educación y Ciencia, Spain and the European Regional Development Fund (ERDF) (Grant BFU2005-24983-E/BFI) and belongs to the "Centro de Investigación Biomédica en Red" for Hepatology and Gastroenterology Research (CIBERehd), Instituto de Salud Carlos III, Spain.

\section{References}

- Ananthanarayanan M, Balasubramanian N, Makishima M, Mangelsdorf DJ, Suchy FJ (2001) Human bile salt export pump promoter is transactivated by the farnesoid $\mathrm{X}$ receptor/bile acid receptor. J Biol Chem 276:28857-28865

- Bender V, Buschlen S, Cassio D (1998) Expression and localization of hepatocyte domainspecific plasma membrane proteins in hepatoma-fibroblast hybrids and in hepatoma dedifferentiated variants. J Cell Sci 111:3437-3450

- Bravo P, Bender V, Cassio D (1998) Efficient in vitro vectorial transport of a fluorescent conjugated bile acid analogue by polarized hepatic hybrid WIF-B and WIF-B9 cells. Hepatology 27:576-583

- Briz O, Macias RI, Vallejo M, Silva A, Serrano MA, Marin JJ (2003) Usefulness of liposomes loaded with cytostatic bile acid derivatives to circumvent chemotherapy resistance of enterohepatic tumors. Mol Pharmacol 63:742-750 
- Briz O, Cassio D, Blazquez AG, Grosse B, Serrano MA, Marin JJ (2007) Characterization of WIF-B9/R cells as an in vitro model with hepatocyte-like polarity and enhanced expression of canalicular ABC transporters involved in phase III of hepatic detoxification. Toxicology. In press

- Buchler M, Konig J, Brom M, Kartenbeck J, Spring H, Horie T, Keppler D (1996) cDNA cloning of the hepatocyte canalicular isoform of the multidrug resistance protein, cMrp, reveals a novel conjugate export pump deficient in hyperbilirubinemic mutant rats. J Biol Chem 271:15091-15098

- Cantz T, Nies AT, Brom M, Hofmann AF, Keppler D (2000) MRP2, a human conjugate export pump, is present and transports fluo 3 into apical vacuoles of HepG2 cells. Am J Physiol Gastrointest Liver Physiol 279:G522-531

- Cassio D, Hamon-Benais C, Guerin M, Lecoq O (1991) Hybrid cell lines constitute a potential reservoir of polarized cells: isolation and study of highly differentiated hepatomaderived hybrid cells able to form functional bile canaliculi in vitro. J Cell Biol 115:1397-1408

- Chan W, Calderon G, Swift AL, Moseley J, Li S, Hosoya H, Arias IM, Ortiz DF (2005) Myosin II regulatory light chain is required for trafficking of bile salt export protein to the apical membrane in Madin-Darby canine kidney cells. J Biol Chem 280:23741-23747

- Decaens C, Rodriguez P, Bouchaud C, Cassio D (1996) Establishment of hepatic cell polarity in the rat hepatoma-human fibroblast hybrid WIF-B9. A biphasic phenomenon going from a simple epithelial polarized phenotype to an hepatic polarized one. J Cell Sci 109:16231635

- Deschatrette J, Weiss MC (1974) Characterization of differentiated and dedifferentiated clones from a rat hepatoma. Biochimie 56:1603-1611

- Donner MG, Keppler D (2001) Up-regulation of basolateral multidrug resistance protein 3 (Mrp3) in cholestatic rat liver. Hepatology 34:351-359 
- Eloranta JJ, Kullak-Ublick GA (2005) Coordinate transcriptional regulation of bile acid homeostasis and drug metabolism. Arch Biochem Biophys 433: 397-412

- Goodwin B, Jones SA, Price RR, Watson MA, McKee DD, Moore LB, Galardi C, Wilson JG, Lewis MC, Roth ME, Maloney PR, Willson TM, Kliewer SA (2000) A regulatory cascade of the nuclear receptors FXR, SHP-1, and LRH-1 represses bile acid biosynthesis. Mol Cell 6:517-526.

- Huang L, Zhao A, Lew JL, Zhang T, Hrywna Y, Thompson JR, de Pedro N, Royo I, Blevins RA, Pelaez F, Wright SD, Cui J (2003) Farnesoid X receptor activates transcription of the phospholipid pump MDR3. J Biol Chem 278:51085-51990

- Ihrke G, Neufeld EB, Meads T, Shanks MR, Cassio D, Laurent M, Schroer T, Pagano RE, Hubbard AL (1993) WIF-B cells: an in vitro model for studies of hepatocyte polarity. J Cell Biol 123:1761-1775

- Ito K, Suzuki H, Horie T, Sugiyama Y (2005) Apical/basolateral surface expression of drug transporters and its role in vectorial drug transport. Pharm Res 22:1559-1577

- Knowles BB, Howe CC, Aden DP (1980) Human hepatocellular carcinoma cell lines secrete the major plasma proteins and hepatitis B surface antigen. Science 209:497- 499

- Konieczko EM, Ralston AK, Crawford AR, Karpen SJ, Crawford JM (1998) Enhanced $\mathrm{Na}^{+}$dependent bile salt uptake by WIF-B cells, a rat hepatoma hybrid cell line, following growth in the presence of a physiological bile salt. Hepatology 27:191-198

- Kubitz R, Sutfels G, Kuhlkamp T, Kolling R, Haussinger D (2004) Trafficking of the bile salt export pump from the Golgi to the canalicular membrane is regulated by the p38 MAP. Gastroenterology 126: 541-553

- Laemmli UK (1970) Cleavage of structural proteins during assembly of the head of bacteriophage T4. Nature 227:680-685

- Lee FY, Lee H, Hubbert ML, Edwards PA, Zhang Y (2006) FXR, a multipurpose nuclear receptor. Trends Biochem Sci 31:572-580 
- Le Vee M, Jigorel E, Glaise D, Grippon P, Guguen-Guillouzo C, Fardel O (2006) Functional expression of sinusoidal and canalicular hepatic drug transporters in the differentiated human hepatoma HepaRG cell line. Eur J Pharm Sci 28:109-117

- Lew JL, Zhao A, Yu J, Huang L, De Pedro N, Pelaez F, Wright SD, Cui J (2004) The farnesoid $\mathrm{X}$ receptor controls gene expression in a ligand- and promoter-selective fashion. $\mathrm{J}$ Biol Chem 279:8856-8861

- Lu TT, Makishima M, Repa JJ, Schoonjans K, Kerr TA, Auwerx J, Mangelsdorf DJ (2000) Molecular basis for feedback regulation of bile acid synthesis by nuclear receptors. Mol Cell $6: 507-515$

- Makishima M, Okamoto AY, Repa JJ, Tu H, Learned RM, Luk A, Hull MV, Lustig KD, Mangelsdorf DJ, Shan B (1999) Identification of a nuclear receptor for bile acids. Science 284:1362-1365.

- Monte MJ, El-Mir MY, Sainz GR, Bravo P, Marin JJG (1997) Bile acid secretion during synchronized rat liver regeneration. Biochim Biophys Acta 1362:56-66

- Nakai D, Nakagomi R, Furuta Y, Tokui T, Abe T, Ikeda T, Nishimura K. (2001) Human liver-specific organic anion transporter, LST-1, mediates uptake of pravastatin by human hepatocytes. J Pharmacol Exp Ther. 297:861-867

- Ng KH, Le Goascogne C, Amborade E, Stieger B, Deschatrette J (2000) Reversible induction of rat hepatoma cell polarity with bile acids. J Cell Sci 113:4241-4251

- Nies AT, Cantz T, Brom M, Leier I, Keppler D (1998) Expression of the apical conjugate export pump, Mrp2, in the polarized hepatoma cell line, WIF-B. Hepatology 28:1332-1340

- Parent R, Marion MJ, Furio L, Trepo, Petit MA (2004) Origin and characterization of a human bipotent liver progenitor cell line. Gastroenterology 126:1147-1156

- Peng X, Grosse B, Le Tiec B, Nicolas V, Delagebeaudeuf C, Bedda T, Decaens C, Cassio D (2006) How to induce non-polarized cells of hepatic origin to express typical hepatocyte 
polarity: generation of new highly polarized cell models with developed and functional bile canaliculi. Cell Tissue Res 323: 233-243

- Sai Y, Nies AT, Arias IM (1999) Bile acid secretion and direct targeting of mdr1-green fluorescent protein from Golgi to the canalicular membrane in polarized WIF-B cells. J Cell Sci 112:4535-4545

- Scharschmidt BF, Lake JR (1989) Hepatocellular bile acid transport and ursodeoxycholic acid hypercholeresis. Dig Dis Sci 34: 5S-15S.

- Shanks MR, Cassio D, Lecoq O, Hubbard AL (1994) An improved polarized rat hepatoma hybrid cell line. J Cell Sci 107:813-825

- St-Pierre MV, Kullak-Ublick GA, Hagenbuch B, Meier PJ (2001) Transport of bile acids in hepatic and non-hepatic tissues. J Exp Biol 204:1673-1686

- Stevenson BR, Siliciano JD, Mooseker MS, Goodenough DA (1986) Identification of ZO-1: A high molecular weight polypeptide associated with the tight junction (zonula occludens) in a variety of epithelia. J. Cell Biol 10:755-766

- Stieger B, Hagenbuch B, Landmann L, Hochli M, Schroeder A, Meier PJ (1994) In situ localization of the hepatocytic $\mathrm{Na}$ /Taurocholate cotransporting polypeptide in rat liver. Gastroenterology 107:1781-1787

- Trauner M, Boyer JL (2003) Bile salt transporters: molecular characterization, function, and regulation. Physiol Rev 83:633-671

- Van Ijzendoorn SC, Van Der Wouden JM, Liebisch G, Schmitz G, Hoekstra D (2004) Polarized membrane traffic and cell polarity development is dependent on dihydroceramide synthase-regulated sphinganine turnover. Mol Biol Cell 15:4115-4124

- Yu J, Lo JL, Huang L, Zhao A, Metzger E, Adams A, Meinke PT, Wright SD, Cui J (2002) Lithocholic acid decreases expression of bile salt export pump through farnesoid X receptor antagonist activity. J Biol Chem 30:31441-31447 
Table 1. Oligonucleotide sequences of primers used in real-time quantitative RT-PCR.

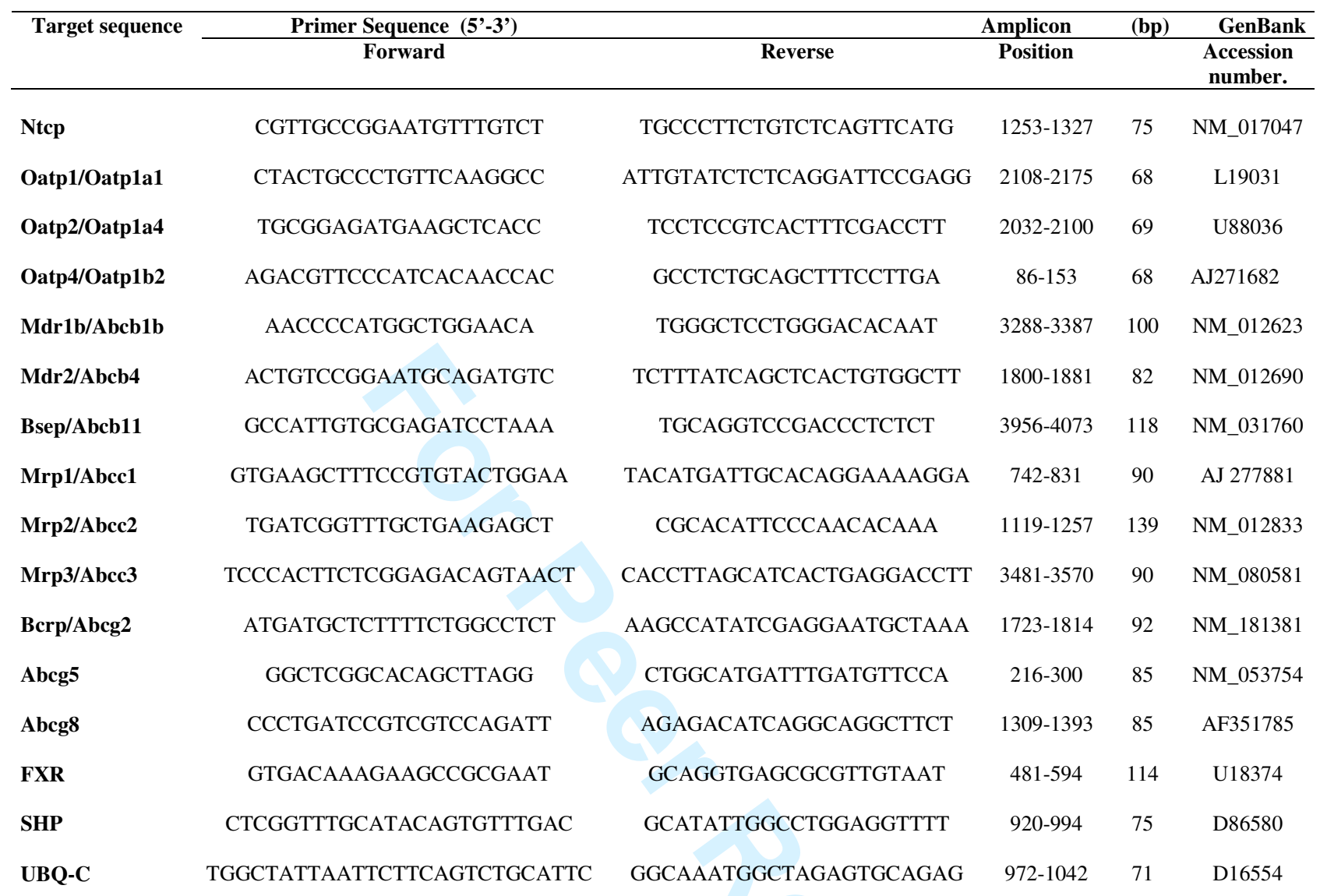




\section{Figures legends}

Figure 1 Expression of thirteen hepatobiliary transporters and two nuclear receptors in Fao cells. Steady state mRNA levels were determined by real-time RT-PCR. They are expressed using a logarithmic scale as \% of mRNA level in rat liver and correspond to the mean of values from three independent cultures. The results shown were normalized using $18 \mathrm{~S}$ rRNA (a similar pattern of expression was obtained using polyubiquitin-C). Liver level is visualized by a dotted line.

Figure 2 Expression of hepatobiliary transporters and nuclear receptors in Can 3-1 and Can 10 cells. Steady state mRNA levels were determined by real-time RT-PCR. They are expressed as \% of corresponding mRNA level in parental Fao cells and are the mean of values from 3 and 4 independent cultures for Can 3-1 and Can 10 lines, respectively. The results shown were normalized using 18S rRNA (a similar pattern of expression was obtained using polyubiquitin-C). Fao level is visualized by a dotted line.

Figure 3 Immunolocalization of apical hepatobiliary transporters in Fao (a-c; j-l) and Can clones (d-i; m-r). Each transporter was colocalized with the tight junction-associated protein ZO-1. In each case the corresponding phase-contrast image is given on the left. Some BC formed by Can 3-1 and Can 10 cells were indicated by short (simple BC formed between two cells) or by long arrows (complex BC). In non-polarized Fao cells, apical transporters $(\mathrm{b}, \mathrm{k})$ were exclusively localized in an intracellular compartment and ZO-1 was discontinuously distributed on the plasma membrane (c,1). In Can 3-1 and Can 10 cells apical transporters were confined in the bile canaliculi $(\mathrm{e}, \mathrm{h}, \mathrm{q})$ delimited by ZO-1 (f,i,r). The anti-Mdr-Pglycoprotein C219 antibody detects Mdr1a, Mdr1b and Mdr2. Due its very low level of expression (Fig. 2), Mrp2 was not detected in Can 3-1 cells (n). Scales: $10 \mu \mathrm{m}$. 
Figure 4 Immunolocalization of basolateral hepatobiliary transporters in Fao (a-c; j-l) and Can clones (d-i; m-r). Each transporter was colocalized with the tight junction-associated protein ZO-1. In each case the corresponding phase-contrast image is given on the left. Some BC formed by Can 3-1 and Can 10 cells were indicated by short (simple BC formed between two cells) or long arrows (complex BC). In non-polarized Fao cells basolateral transporters $(\mathrm{b}, \mathrm{k})$ were mostly present on the whole plasma membrane and ZO-1 was discontinuously distributed on this membrane (c,1). In Can 3-1 and Can10 cells basolateral transporters $(\mathrm{e}, \mathrm{h}, \mathrm{n}, \mathrm{q})$ were excluded from the canaliculi sealed by ZO-1 (f,i,o,r). and present on the rest of the PM and in the cytoplasm. Scales: $10 \mu \mathrm{m}$.

Figure 5 Effects of bile acids on the expression of hepatobiliary transporters and nuclear receptors in Fao and Can 10 cells (a-o). Steady state mRNA levels, determined by real-time RT-PCR, were expressed as \% of corresponding mRNA level in cells cultured with DMSO and without bile acids. They are the mean of values from 2-3 independent cell cultures. The results shown were normalized using $18 \mathrm{~S}$ rRNA or polyubiquitin-C; similar results were obtained in both cases. * $\mathrm{p}<0.05$ when compared to cells cultured with DMSO and without bile acids.

Figure 6 Effects of bile acids on Mdr protein level in Fao and Can clones. Western blot (a). Each lane was loaded with a cell lysate aliquot ( $25 \mu \mathrm{g}$ of total protein). Mdr proteins (detected with the C219 antibody that recognizes Mdr1a, Mdr1b, Mdr2) were codetected with $\alpha$ tubulin. Mdr level was normalized using $\alpha$-tubulin as the internal control and expressed as $\%$ of the level of DMSO treated cells (b). The experiment was performed three times with lysates from 2-3 independent cultures. One representative experiment is show. In all cases a significant increase in Mdr level was obtained in Fao and Can 10 cells treated with CDCA. 
Compared to liver, Fao and both Can clones expressed a higher Mdr protein level; this result is in agreement with measurement of Mdr mRNA level (Fig. 1, Fig. 2).

Figure 7 Effects of bile acids on the polarity of Can 10 cells.

Immunolocalization of the apical marker DPPIV in cells treated by bile acids (a-h). In each case the corresponding phase contrast image is given on the left. DPPIV is present at the membrane of BC, that are greatly inflated (*) in CDCA and UDCA-treated cells. Confocal analysis of the localization of the apical transporter Mrp2 with the tight junction-associated protein ZO-1 in cells treated by bile acids (i-x). In each case, the localization of Mrp2, ZO-1, and the corresponding merge image (compilation of 20-30 xy sections taken in $0.3 \mu \mathrm{m}$ steps) are shown (left to right) followed by one xy section taken in the middle of the cell layer. Note the marked enhancement of the volume of BC in CDCA and UDCA-treated cells, particularly well visible in the xy sections. Scales: $10 \mu \mathrm{m}$.

Figure 8 Confocal analysis of the localization of apical Mdr transporters (detected with the C219 antibody) with the tight junction-associated protein ZO-1 in DMSO and CDCA treated Can 3-1 (a-d) and Can 10 cells (e-h). For each culture an image corresponding to a compilation of 18-21 xy sections and a graph of the distribution of Mdr along the dotted line indicated on the corresponding compilation are shown. Note that Mdr proteins are well concentrated at the BC of Can 3-1 only after CDCA treatment (c,d). In contrast these apical markers are already highly concentrated at the BC of Can 10 cells cultured without CDCA (e,f). Scales: $10 \mu \mathrm{m}$.

Figure 9 Effects of bile acids on tight junction paracellular permeability of Can clones, evaluated by measuring the paracellular diffusion of FITC-dextrans (molecular weight 4,400) 
into the BC. The values are means from $2-3$ independent cell cultures. * p $<0.05$ when compared to untreated cells. 


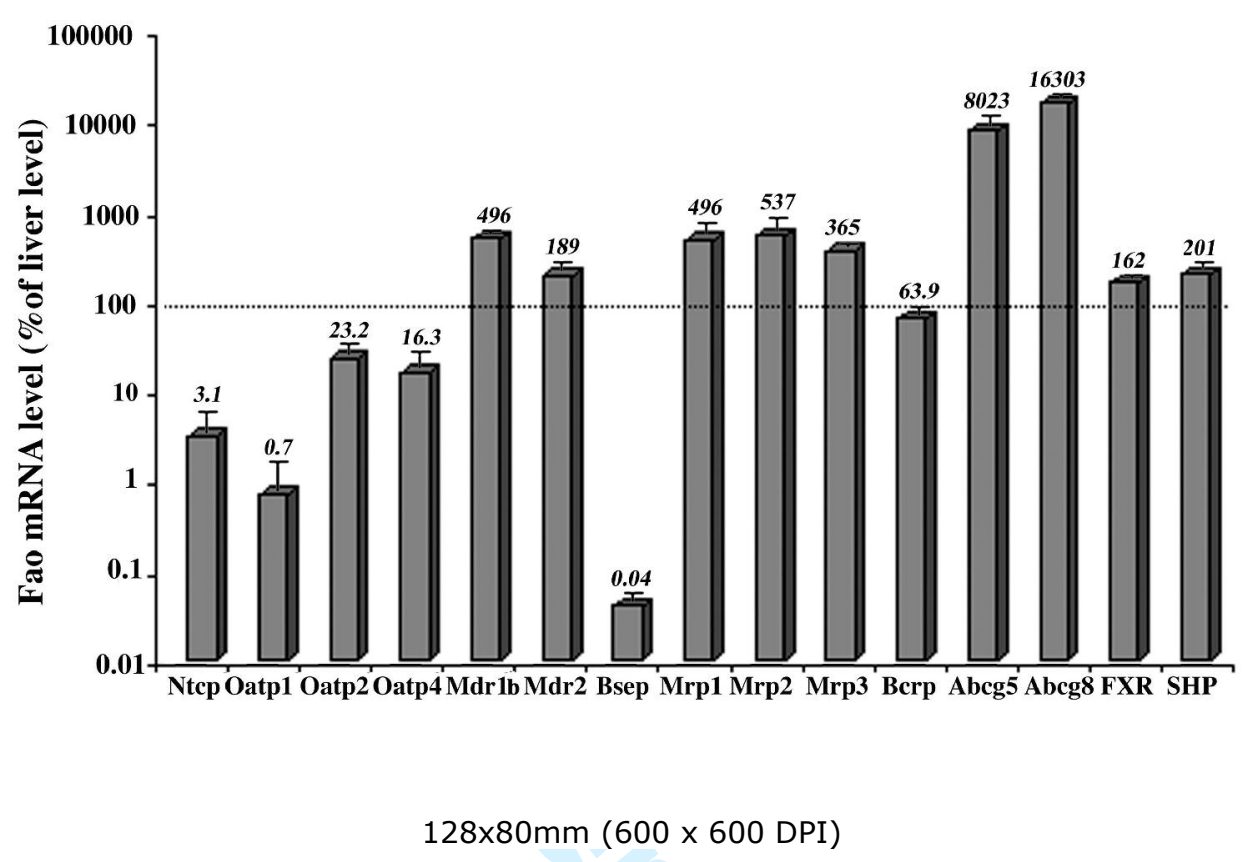




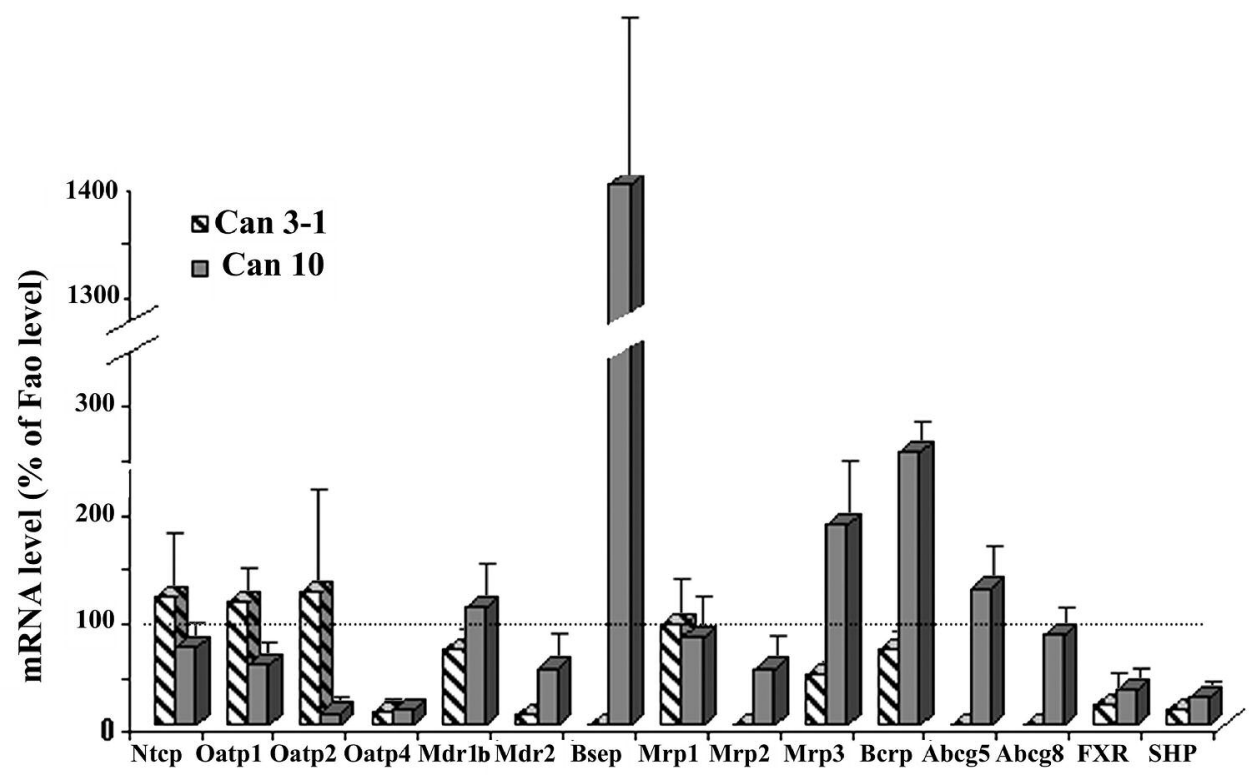

$128 \times 80 \mathrm{~mm}(600 \times 600 \mathrm{DPI})$ 


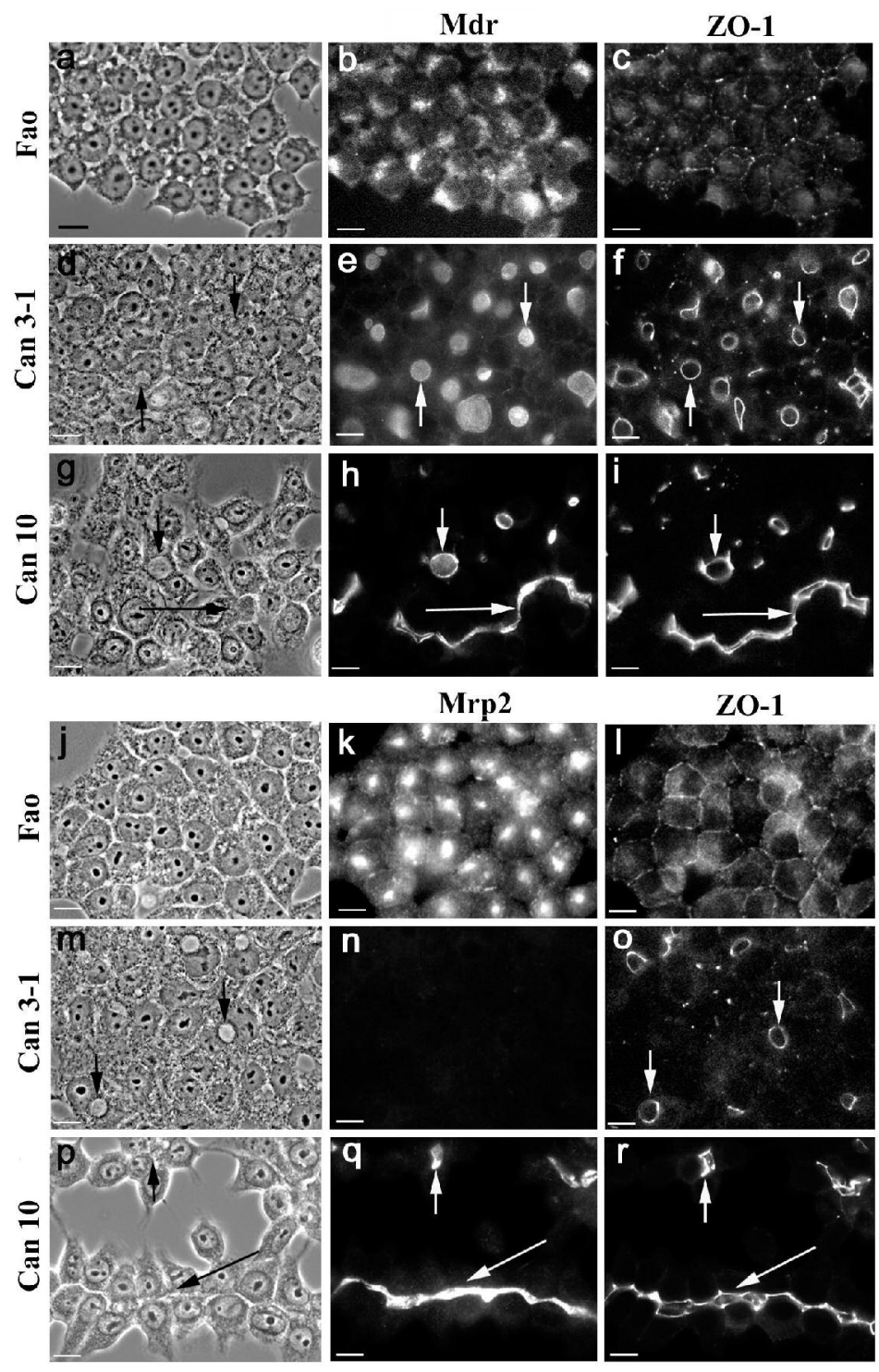

$129 \times 199 \mathrm{~mm}(300 \times 300$ DPI $)$ 

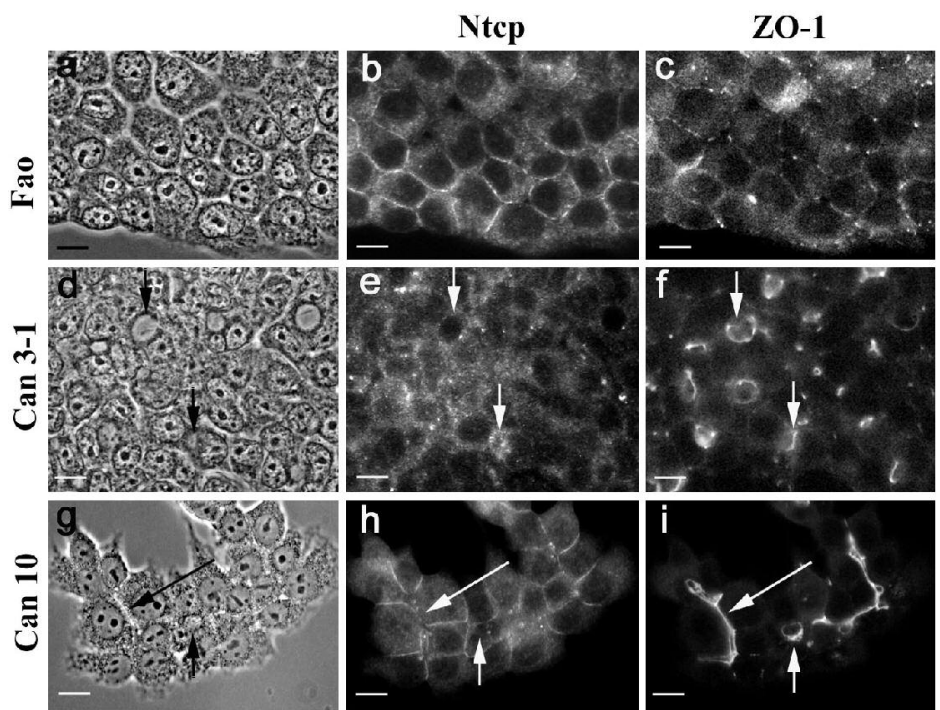

Mrp3

ZO-1
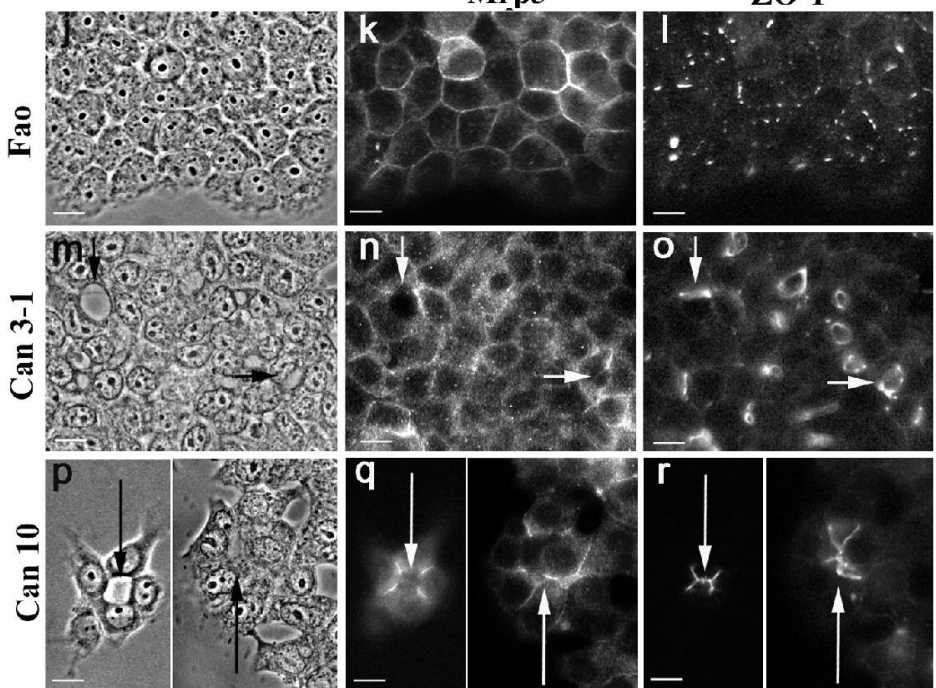

$129 \times 199 \mathrm{~mm}(300 \times 300 \mathrm{DPI})$ 


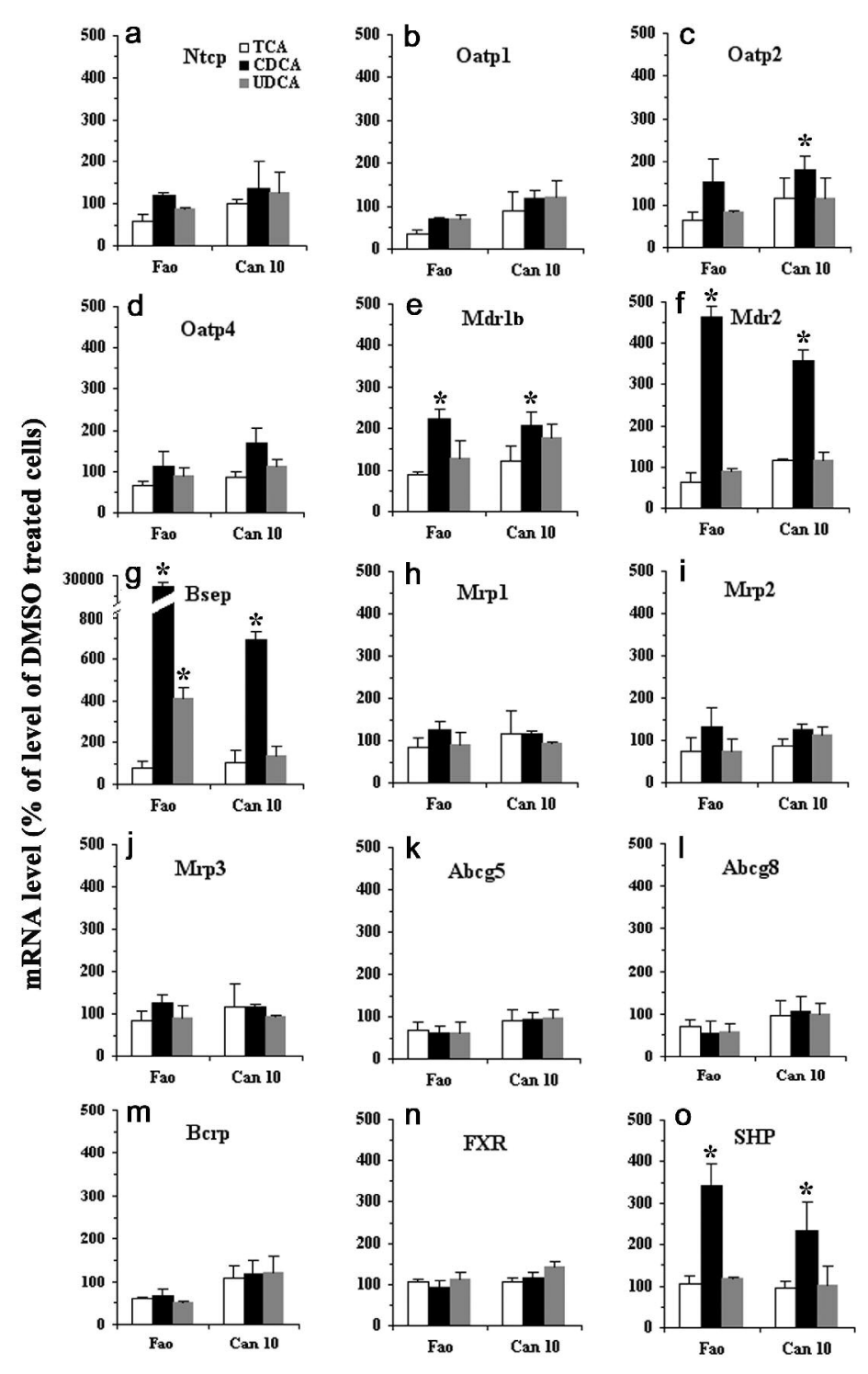

$128 \times 199 \mathrm{~mm}(600 \times 600$ DPI $)$ 


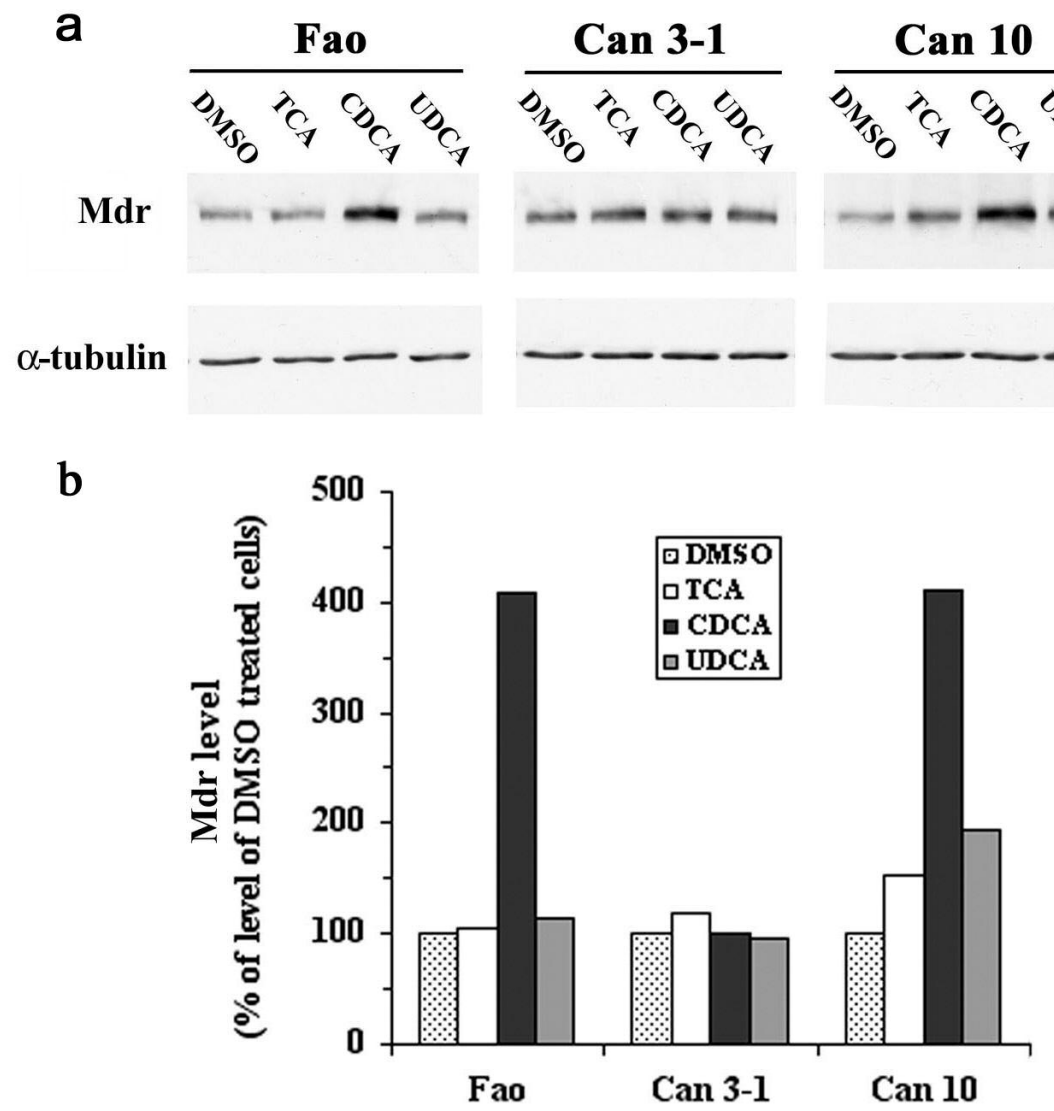

129×119mm (300 x 300 DPI) 


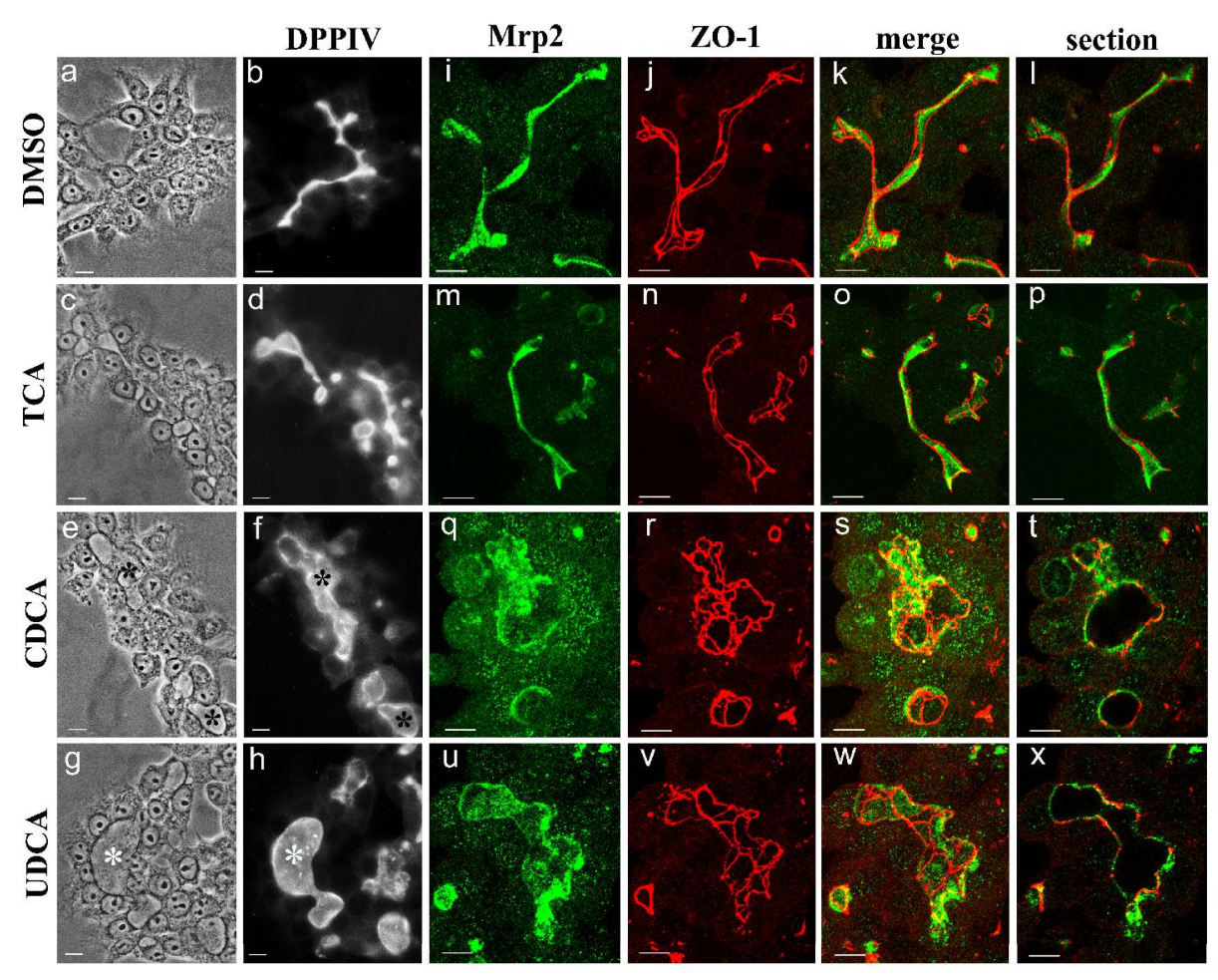

$173 \times 139 \mathrm{~mm}(600 \times 600$ DPI $)$ 
Can 3-1

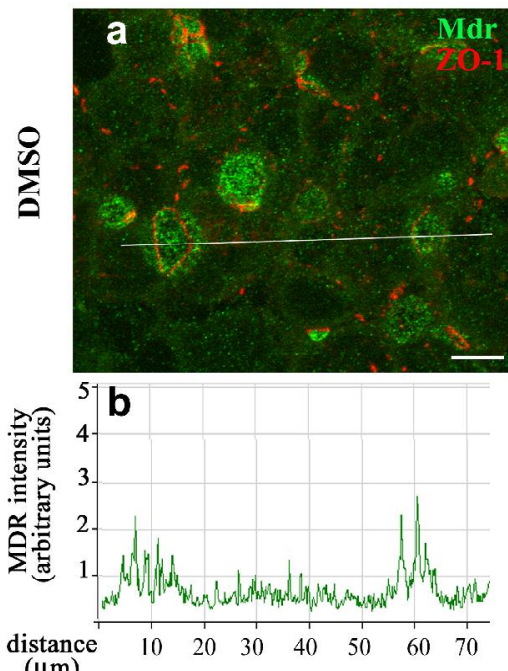

( $\mu \mathrm{m})$
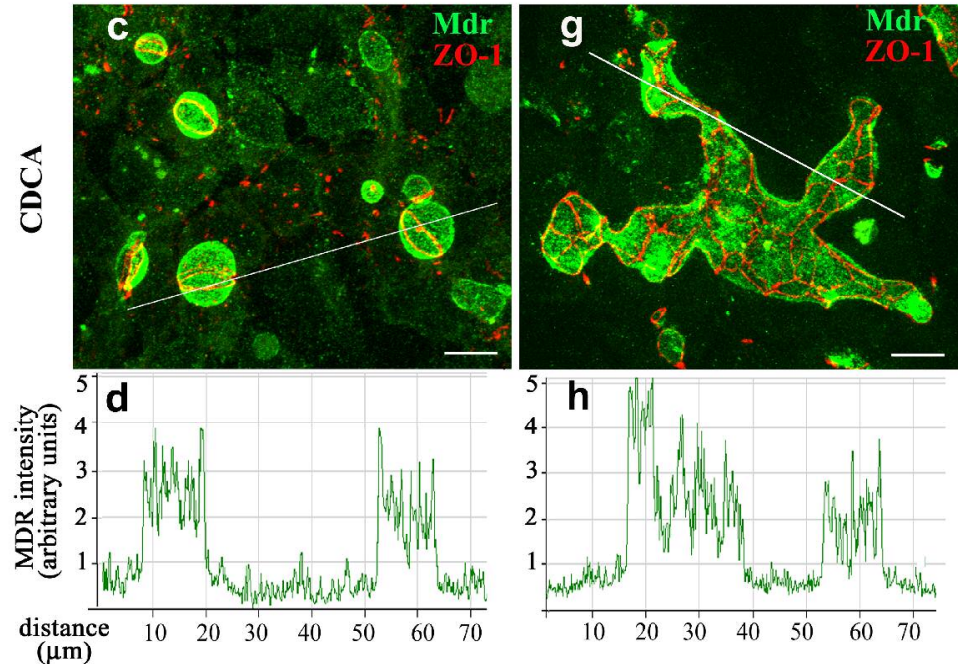


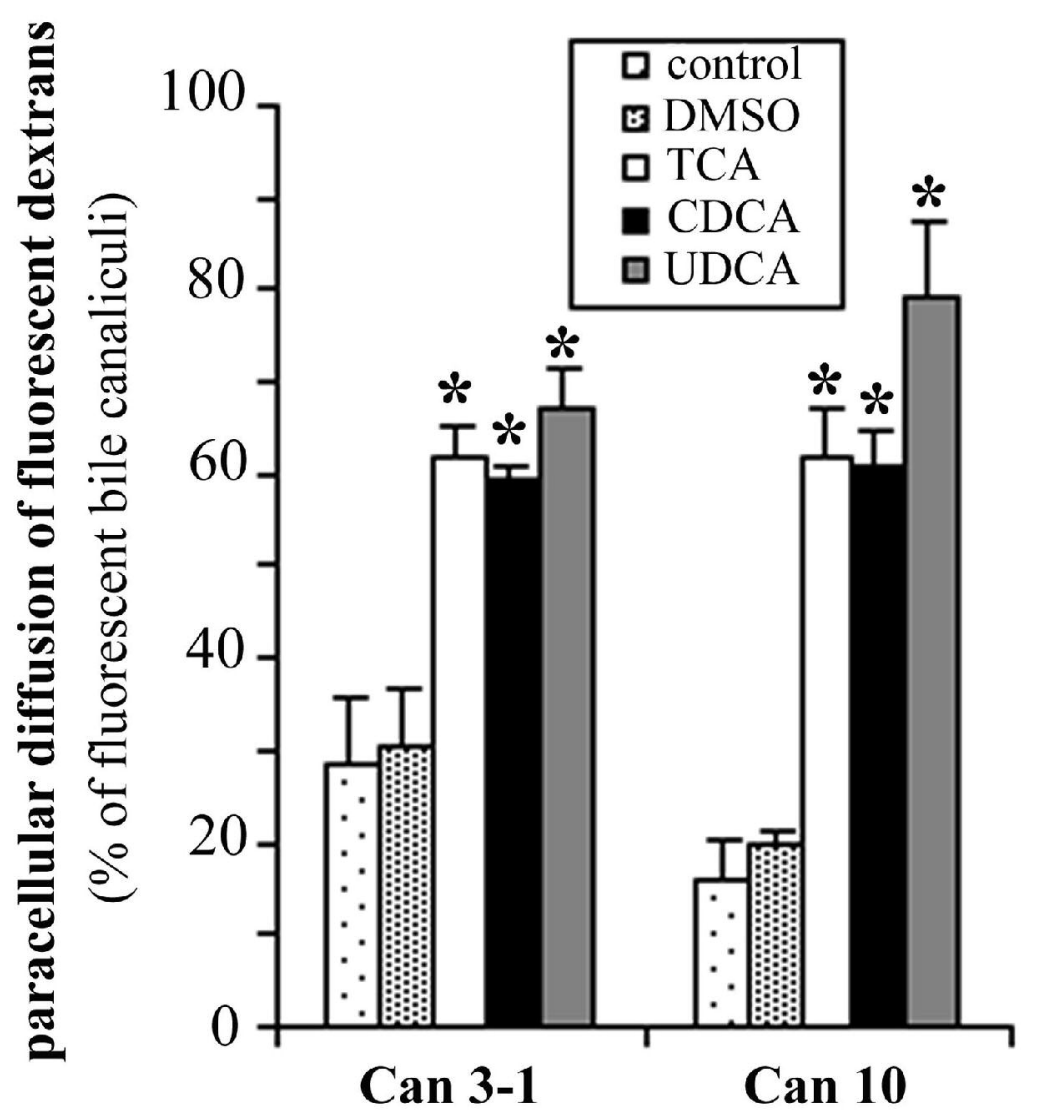

$83 \times 80 \mathrm{~mm}(600 \times 600 \mathrm{DPI})$ 